\title{
The hypothesis of formation of the structure of surfaced metal at the surfacing based on the application of the prognostic algorithm of control the electrode wire speed
}

\author{
Lebedev V. A., Novykov S. V.
}

Paton Electric Welding Institute of the National Academy of Sciences of Ukraine, 11 Bozhenka St., 03680, Kyiv, Ukraine

\author{
Article info: \\ Paper received: \\ The final version of the paper received: \\ Paper accepted online:
}

September 13, 2017

November 25, 2017

November 28, 2017

\author{
*Corresponding Author's Address: \\ novykov76@ukr.net
}

\begin{abstract}
The growth of a drop in the process of surfacing by a consumable electrode is characterized by a linear dependence of the current change on time. A hypothesis has been put forward, according to which a reduction in the feed rate of the electrode wire to zero in this time interval will substantially reduce the spraying loss and improve the formation of the surfacing roller. For the implementation of which, the use of regulators with a typical law of regulation is proposed, but not according to the current value of the arc current, but according to the forecast. A key feature of these researches is a realization given surfacing process with the imposition of external mechanical oscillations with specified amplitude-frequency characteristics on the welding bath. Analytical calculation of the transfer function for the prognostic PID regulator with the simplest linear prediction taking into account the oscillation of the weld pool is given.
\end{abstract}

Keywords: prognostic regulator, welding pool oscillations, surfacing.

\section{Introduction}

It has been experimentally established that at the moment of the drop growth, the arc current changes linearly. If the wire feed speed is reduced to zero during this period, the liquid bridge period will reduce by 1.7 times at compared to the surfacing mode with a constant wire feed speed. The minimum short-circuit current is reduced by $20 \%$, that is followed the reduce of the metal spraying loss and the introduced heat quantity into the base metal. The wire feed pulses frequency should be close to or equal to the transfer drops frequency to the weld pool. This mode is provided by an electrode wire feed control system based on automatic controllers.

The use of automatic regulators in the modern industry is due to their simple design and application. In welding industry, they are used both for the control and automation of the welding process itself, and for the consumables production, for example, electrodes.

Work [1] it is shown that the wide application of classical PID regulators in the automatic control system of an electric furnaces of resistance for the electrodes production does not fully provide performance of the static and dynamic parameters due to the furnace parameters drift. To solve this problem, it is proposed a multiprocessor adaptive control system introduction where in the basic circuit is applied the regulator of a state, the method of standard coefficients - as an adapter in the corresponding contour, and the least-squares method - as an identifier. This adaptive control system is implemented on the Linux operating system platform.

The control systems based of automatic regulators are rising an efficiency enhance of the widely used welding technologies in the industry.

So, in work [2] at the development of the model of single-pass automatic argon-arc welding of butt joints made of stainless steel, the control system for root width is built on the basis of a PID controller controlling the welding current according to a given law. The coefficients of the PID controller are determined by the CHR method (Chien, Hrones, Reswick), which allows to obtain a small overshoot and a fast transient process. Moreover, in addition to the width control of the seam root, a system for stabilizing the welding speed on the basis of the PID regulator is built.

In work [3] results of researches by perfection of welding technology of angular seams by curvilinear trajectory by means of the welding robot are resulted, where on a basis of the PID regulator the complex of welding speed regulation has been created. The input signal was the preassigned welding speed, and the output signal - the robot center speed. The regulating coefficients were determined experimentally. The results of the experiments showed that the welding speed adjustment by the PID controller made it possible to carry out the welding process with any given curvature radius without significantly the weld- 
ing speed reducing, that is the efficiency of welding operations significantly is increased.

The authors of [4] studied the use of the PID regulator at automatic welding; the aim was to control the weld pool protection (SMAW process) as an arc current function, which was determined by the deviation from the set value of the feed rate of the electrode wire. The working of the PID controller was obeyed by the GA algorithm (genetic algorithm). The PID controller coefficients were selected during the simulation process.

The monitoring and control of the welding process's energy parameters, such as current and voltage, are currently implemented in the form of separate control units [5] and monitoring systems for the output current and voltage values in the power supply design.

In work [6] some features of designing modern power supplies with microprocessor control are given. A feature of such sources is the application in their design instead of the wide-pulse modulators of the Fuzzy controller with a special program generates the set values of the output current and voltage through power switches. These fuzzy controllers can be used as PID regulators not only for current and voltage, but also for other welding process parameters, for example, temperature. The control coefficients are determined by means of the function Fuzzy Logic- an algorithm of multipara meter logic. In work [7] the PID controller, applied as part of the underwater welding machine and controlled by Fuzzy Logic algorithms was presented, it is made possible to effectively control the welding process parameters on the assumption of the specified parameters of the weld bead geometry.

As can be seen from the above, recently the control on a base of PID controllers of various technological processes are provided with complex algorithms, of which Fuzzy Logic and GA algorithm are widely used. The comparative analysis of GA - algorithm is described in detail in [8]. At the same time, the authors of [9] believe that it is possible to significantly improve the efficiency of algorithms of standard regulators without resorting to the use of expensive and complex control systems. To do this, it is enough to modify them insignificantly so that the control is not performed according to the current value of the output quantity $-I_{\text {arc }}(t)$, but according to the forecast $-I_{a r c}\left(t+\tau_{f r}\right)$, where $\tau_{f r}$ is the time through which the control error occurs.

The prognostic regulator consists of 2 parts - a regulator with a typical law of control $W(p)$ and a previous forecast element with a transfer function $W_{f r}(p)$ or some nonlinear function $f\left(I_{a r c}, t\right)$. The element has a memory into which the given linear law of arc current change is introduced $-I_{\text {arc }}^{o}(t)=A+I_{o}$, where $A$ and $I_{\mathrm{o}}$ are given constants. By determining the value of the difference $I_{\text {arc }}{ }^{o}(t)-I_{\text {arc }}^{\text {tec }}(t)$, where $I_{\text {arc }}^{\text {tec }}(t)$ - law of variation of the current value of the controlled variable, the forecasting element converts the value of this difference into a regulation error signal $-\varepsilon_{n p}=I_{a r c}{ }^{o}(t)-I_{a r c}\left(t+\tau_{f r}\right)$, expected through the regulation time $\tau_{f r}$, according to which, in accordance with the adopted typical law, a regulating acting is formed

$$
\mu=\left\{\begin{array}{c}
0 ; \quad \varepsilon_{f r}=0 ; V_{w f} \neq 0 \\
f(t) ; \quad \varepsilon_{f r} \neq 0 ; V_{w f}=0,
\end{array}\right.
$$

where $V_{w f}-$ wire feed speed; $f(t)$ - specified control algorithm.

As is known, when surfacing in a carbon dioxide environment, one of the significant drawbacks is the large spattering loss, and at the external oscillations are applied to the weld pool melt, this one only increases. The main cause of the splashing is considered to be a burst of the bridge, which is characterized by a certain value of the current that connects a drop of molten metal to the electrode wire end. Then using the prognostic regulator, it can be set the wire feed mode so that during the growth period of the drop the feed rate is zero, and the drop size is determined by the specified amplitude-frequency characteristics of the weld pool oscillation.

The dependences of the arc burning time and the short circuit time on the prescribed law of weld pool oscillation will obtain analytically; on the basis of there the work algorithm of the prognostic regulator can be predetermined.

\section{Results}

The following expression of the arc current at the surfacing with weld pool oscillations according to the law $\psi(t)=2 \pi f_{o p} t$ (Fig. 1) was obtained [10], where $f_{o p}$ - given frequency of weld pool oscillation, dependent on the welding speed:

$$
I_{a r c}=I_{s c}-D l_{a r c}^{\frac{3}{8}}
$$

where $I_{s c}[\mathrm{~A}]$ - the short circuit current; $D[\mathrm{~A} / \mathrm{m}]$ - coefficient of proportionality, determined experimentally as a function of the welding current; $l_{\text {arc }}-$ length of the arc, in the conditions of external oscillations defined as [11]: $l_{\text {arc }}=\delta e^{-\frac{t_{s r}}{\theta}}$, where $\delta=a \cdot \operatorname{tg}\left(2 \pi f_{o p} \tau\right)[\mathrm{m}]-$ amplitude of oscillation of the welding arc; $t_{s r}[\mathrm{~s}]-\operatorname{arc}$ self-regulation time; $\theta[\mathrm{s}]$ - the self-regulating constant of arc; $a[\mathrm{~m}]-$ horizontal distance from the oscillation axis to the weld pool; $\tau[\mathrm{s}]-$ the arc burning time to short circuit.

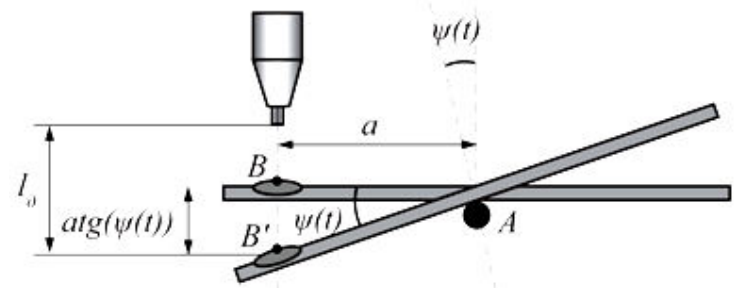

Figure 1 - Scheme to explain the dependence of the arc length on the frequency characteristics of the weld pool oscillation

Then for the time interval of drop growth we can write:

$$
A \tau_{a r c}+I_{0}=I_{s c}-D\left[a \cdot \operatorname{tg}\left(2 \pi f_{o p} \tau_{a r c}\right) e^{-\frac{t_{s r}}{\theta}}\right]^{\frac{3}{8}},
$$


whence it can be found $\tau_{\text {arc }}$ - interval of arc burning time during which the drop growth occurred $\left(\tau>\tau_{\text {arc }}\right)$, but the dependence of the arc current on time was linear $I_{\text {arc }}{ }^{o}(t)=A+I_{o}$. This equation for $\tau_{\text {arc }}$ is transcendental and can only be solved approximately.

In view of the foregoing, for the simplest linear forecast the transfer function in the general form will be: $W_{p r}(p)=1+p \tau_{f r}=1+p\left(\tau_{a r c}+m T\right)$, where $p-$ complex variable; $T=\tau_{a r c}+\tau_{s c}-$ arc burning period; $\tau_{s c}-$ shortcircuit time; $m$ - natural number. The time $\tau_{s c}$ is determined from the current density formula obtained analytically as well [10]:

$$
j=\sqrt{3} \frac{n e_{e l} \lambda}{a \cdot \operatorname{tg}\left(2 \pi f_{o p} \tau_{s c}\right) e^{-\frac{t_{s r}}{\theta}} K},
$$

where $j\left[\mathrm{~A} / \mathrm{m}^{2}\right]$ - short circuit current density; $n$ - natural number, increasing with increasing $j ; e_{e l}-$ electron charge; $\lambda[\mathrm{W} / \mathrm{m} \cdot \mathrm{K}]-$ thermal conductivity coefficient; $K[\mathrm{~J} / \mathrm{K}]$ - Boltzmann's constant. Whence:

$$
\tau_{s c}=\frac{1}{2 \pi f_{o p}} \operatorname{arctg}\left(\frac{\sqrt{3} n e_{e l} \lambda}{a j e^{-\frac{t_{s r}}{\theta}} K}\right) .
$$

Then the transfer function, for example, of the prognostic PID controller will be represented by the following expression:

$$
\begin{aligned}
& W_{P I D}^{p r}(p)=W_{P I D}(p) W_{p r}(p)= \\
& =k_{p}\left(1+\frac{1}{T_{I} p}+T_{D} p\right)\left\{1+p\left[\tau_{\text {arc }}+m\left(\tau_{\text {arc }}+\tau_{s c}\right)\right]\right\}
\end{aligned}
$$

where $k_{p}$ - coefficient of regulator transfer; $T_{I}$ - integration time constant; $T_{D}$ - differentiation time constant.

In accordance with obtained the expression (5), an additional link $W_{P I D}^{p r}(p)$ was introduced into the regulator of the electric drive of the feed mechanism synthesized by [12], which makes it possible to substantially increase the productivity of the electrode wire supply system generally, and consequently to increase the efficiency of surfacing process control, including with controlled oscillations of the weld pool.

Partial confirmation of the obtained conclusions for the development of a prognostic regulator with a period of $T=0.05 \mathrm{~s}$ (data of [13]) can be seen in Fig. 2, where the wire feed speed oscillograms have been presented for comparison, at there are providing integral the value of the current $I_{a r c}=180-200$ A, when surfacing the electrode wire Sv08G2 with a diameter of $1.2 \mathrm{~mm}$ in $\mathrm{CO}_{2}$.

The use result of the prognostic regulating is to reduce the splashing (loss) of the electrode metal by $10-12 \%$ in comparison with conventional systems, as well as some improvement in the shape of the weld bead, which can be seen in the Fig. 3 of the compared rollers photos.
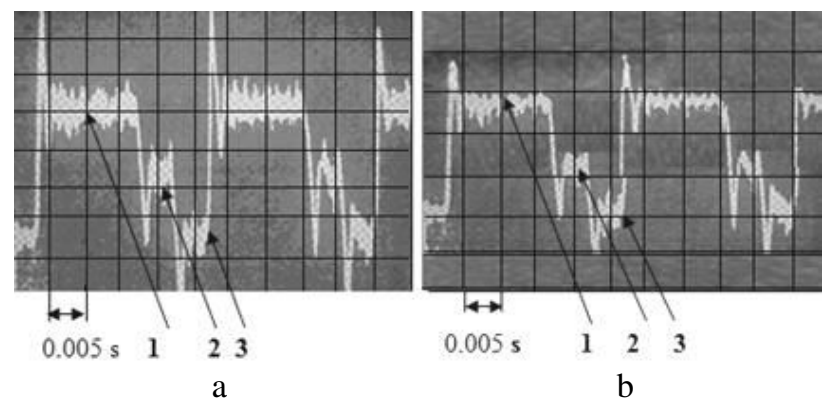

Figure 2 - The oscillogram of the impulse speed of feed with an ordinary regulator (a) and at the predicativ (prognostic) regulation (b): 1 -impulse; 2 - pause; 3 - reverse

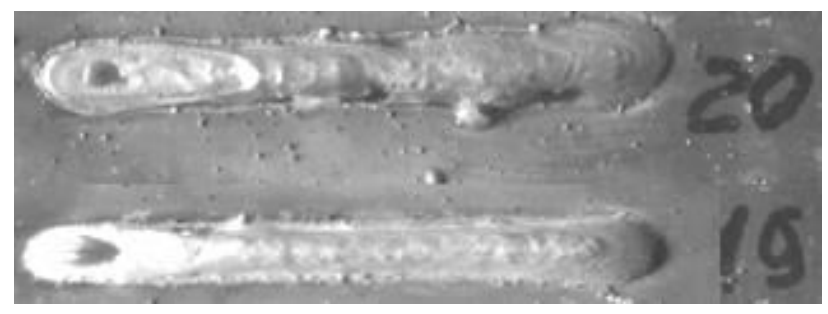

Figure 4 - The characteristic surfacing beads obtained by using various methods of regulation for feeding the electrode wire with a prognostic regulator (19) and an ordinary regulator (20)

\section{Conclusions}

In order to reduce the metal spattering at the surfacing on a direct current with external oscillations of the weld pool, carried out by a predetermined law, the hypothesis of using predictive regulators based on widely applicable regulators (PI, PID, P) with optimal control algorithms has been put forward.

The analytical equation for calculating the drop growth time and the expression for the short-circuit time interval are presented on the basis of which the transfer function of the predictive PID controller was calculated.

These results have in the main theoretical character, that cause to the further experimental researches to verify the obtained analytical dependencies with the experimental data. 


\section{References}

1. Smirnov, M. A. (2012). Razrabotka multiprocessornoy sistemy adaptivnogo upravleniya elektricheskimi pechami soprotivleniya [Development of a multiprocessor system for adaptive control of electric furnaces of resistance: thesis of the candidate of technical sciences dissertation], Ivanovo, pp. 20 [in Russian].

2. Perkovskiy, R. A. (2010). Razrabotka phisiko-mathematicheskih modeley i mikroprocessornyh sistem kontrol'a i upravleniya processom arghonodugovoy svarki tonkostennyh izdeliy otvetstvennoho naznacheniya [Development of physical-mathematical models and microprocessor systems for monitoring and controlling the process of argon-arc welding of thin-walled products of responsible designation: thesis of the candidate of technical sciences dissertation], Moscow, pp. 17 [in Russian]

3. Cuong, N. D., \& Lubenco, V. N. (2009). Soverchenstvovanie processa svarki uglovyh schvov krivyh i gofrirovanych konstrukciy sudna mobil'nym svarochnym robotom [Improvement of the process of fillet welding of bent and corrugated ship constructions with mobile welding robot]. Vestnik of Astrakhan State Technical University. Series: Marine Engineering and Technologies, No. 1, 66-71 [in Russian].

4. Huang, Y.-W., Tung, P.-C., \& Wu, C.-Y. (2007). Tuning PID control of an automatic arc welding system using a SMAW process. The International Journal of Advanced Manufacturing Technology, Vol. 34, Issues 1-2, No. 8, 56-61.

5. Chichicalo, N. I., Vinnichenko, N. G., \& Tomilin ,E. M. (2009). Proektirovanie blokov formirovaniya zakonov regulirovaniya dl'a priborov kontrol'a i upravleniya tehnologicheskimi processami [Control law preform blocks design which use in control and monitoring devices of the manufacturing methods]. Scientific Herald Donetsk national technical the university, Vol.148, 69-78 [in Russian].

6. Sergeev, P. (2009). Osobennosti proektirovaniya istochnikov pitaniya svarochnoy dugi s mikroprocessornym upravleniem [The features of designing a power supplies for a welding arc with microprocessor control]. Power electronics, No. 5, $94-97$ [in Russian].

7. Omajene, J. E., Kah, P., Wu, H., Martikainen J., \& Izelu, C. O. (2015). Intelligent control mechanism for underwater wet welding. International Journal of Mechanical and Applications, Vol. 3, Issue 4, No. 8, 50-56.

8. Chopra, V., Singla, S. K., \& Dewan, L. (2014). Comparative Analysis of Tuning a PID Controller using Intelligent Methods. Acta Polytechnica Hungarica, Vol. 11, No. 8, 235-249.

9. Pikina, G. A. (2014). Realizaciya principa upravleniya po prognosu v avtomaticheskih sistemah reguliovaniya [An introduction of the management principle by the forecasting in the automatic systems of control]. The Proceedings of the 12th All-Russian Meeting on Governance problems VSPU-2014. Moscow, The Institute of Management Problems, pp. 200-211 [in Russian].

10. Lebedev, V. O., Novykov, S. V., Drahan, S. V., \& Simutienkov, I. V. (2017). Matematisheskaya model' processov svarki i naplavki s upavl'aemymi izmeneniyami vyleta elektrodnoy provoloki [Mathematical model of welding and surfacing process with controlled changes in the outlet of the electrode wire. Collection of Scientific Publications, Mykolaiv, No. 1, 48-54 [in Russian].

11. Leskov, G. I. (1970). Elektrisheskaya svaroshnaya duga [The electric welding arc]. Mashynostroyeniye, Moscow, pp. 177-179 [in Russian].

12. Lebedev, V. A., Guly, M. V. (2014). Bystrodeystvuyuschiy ventel'niy elektroprivod dl'a oborudovaniya mhanizirovannoy dugovoy svarki [The high-speed valve electric drive for the equipment of the mechanized arc welding]. Mechatronics, Automation, Control, No. 6, 47-51 [in Russian].

13. Potapievsky, A. G. (2007). Svarka v zasshitnyh gazah plavyasshimsya elektrodom [The welding in protective gases by a melting electrode]. Welding in active gases. Kiev, Ekotehnologiya, Vol. 1, pp. 192. [in Russian]. 